\title{
Socio-Structural Intergroup Characteristics as Predictors of Intention to Join University Alumni Association
}

\author{
Gideon Mazambani ${ }^{1}$, Stephen Reysen ${ }^{1, *}$, Shonda Gibson ${ }^{1} \&$ LaVelle Hendricks $^{1}$ \\ ${ }^{1}$ Department of Psychology, Counseling, and Special Education, Texas A\&M University-Commerce, Commerce, TX, \\ 75429, USA \\ *Correspondence: Department of Psychology, Counseling, and Special Education, Texas A\&M \\ University-Commerce, Commerce, TX, 75429, USA. E-mail: Stephen.Reysen@tamuc.edu
}

Received: April 10, 2017

Accepted: April 27, 2017 Online Published: July 5, 2017

doi:10.5430/wjss.v4n2p42

URL: https://doi.org/10.5430/wjss.v4n2p42

\begin{abstract}
We examined the association between socio-structural intergroup characteristics (i.e., permeability of group boundaries, legitimacy of status difference between ingroup and outgroups, stability of status difference) and students' intention to join the university alumni association. Prior theory and research suggests that group members assess the intergroup context to direct identity management strategies (e.g., leave group, collective action). College students in their last semester at a university were asked to rate the perceived socio-structural characteristics of the ingroup (compared to other universities) and their intention to join the alumni association. The results showed that perceiving one's ingroup as legitimately high status and in a stable intergroup context predicted greater intention to join the alumni association. Consistent with prior theory, the results suggest that viewing one's ingroup as legitimately high status predicts endorsement of actions to maintain a positive and distinct identity.
\end{abstract}

Keywords: alumni association, socio-structural characteristics, permeability, legitimacy, stability, social identity

\section{Introduction}

Institutions of higher learning are operating in conditions of a bad economy and dwindling financial assistance from governments (Archibald \& Feldman, 2006; McLendon, Hearn, \& Mokher, 2009; Weerts \& Ronca, 2006) and are increasingly relying on private charitable giving to meet their financial needs (Drezner, 2011). In 2012, alumni giving constituted $24.8 \%$ of total voluntary giving and rose to $26.6 \%$ in 2013 (Voluntary Support for Education, 2013). An alumni association, a group of former students, assists the institution with raising funds and fosters connection between alumni and the university (Arnold, 2003; Gill, 1998). Alumni associations typically organize social events with the dual purpose of fostering relationships for its members and to provide cultivation that encourages future giving. For recent graduates, the alumni association allows professional networking that can provide career opportunities as well as a group of people who share similar experiences. Joining the alumni association thus provides a way for alumni to contribute towards the success of their alma matter and to connect with other former students. In the present study we examine predictors of students' intention to join the alumni association.

\subsection{Predictors of Alumni Association Membership}

The characteristics of the university and the quality of experiences for students influence alumni giving (Baade \& Sundberg, 1996; Clotfelter, 2001; Gaier, 2005; Holmes, 2009). University characteristics such as age (Duronio \& Loessin, 1990), quality of career services provided (McDearmon, 2010; Pryor, Hurtado, Sáenz, Santos, \& Korn, 2007), graduation rate (Gunsalus, 2004), perceived academic quality and prestige (Baade \& Sundberg, 1996; Belfield \& Beney, 2000; Hanson, 2000; Leslie \& Ramey, 1988; Mael \& Ashforth, 1992), and success in athletics (Coughlin \& Erekson, 1984; Holmes, 2009) are predictors of giving back to the university. Unlike young universities, established universities tend to have the advantage of having name recognition, an established culture, and older alumni who are more likely to have the financial resources to give back to the university (Baade \& Sundberg, 1996).

Whereas most students go to college with the goal of achieving financial success after graduation (Pryor et al., 2007), 
the extent to which students perceive the university's contribution to their careers through adequate provision of career services influences future giving (McDearmon, 2010). Students who are satisfied with their undergraduate experiences (Baade \& Sundberg, 1996; Monks, 2003), engage in campus activities (Hanson, 2000; Holmes, 2009; Wunnava \& Lauze, 2001), or get involved in university related events after graduation (Hanson, 2000) are more likely to donate to the university because the experiences increase identification with the university (Baade \& Sundberg, 1996). Success in athletics provides name recognition and has an impact on academic success because the visibility attracts more applicants (McCormick \& Tinsley, 1987; Mixon, 1995; Mixon, Trevino, \& Minto, 2004). Together, the prior research shows that the perceived status of the university, whether emanating from the age of the institution, student experiences, perceived academic status and prestige, or success in sports, predicts the intention or actual joining of the alumni association.

\subsection{Socio-Structural Intergroup Characteristics}

According to the social identity theory (Tajfel \& Turner, 1979), individuals utilize features of the intergroup context in their search to gain or maintain a positive and distinct social identity. Ingroup members compare the status of their group to similar outgroups and when they differ in status, they use a combination of three socio-structural variables (stability, legitimacy, and permeability) to influence individual and group actions that facilitate gaining or maintenance of a positive social identity (Bettencourt, Dorr, Charlton, \& Hume, 2001; Ellemers, 1993; Mummendey, Klink, Meilke, Wenzel, \& Blanz, 1999). Stability describes whether the ingroup and outgroup status differences are perceived to be permanent or temporary. Legitimacy describes the perceptions of status differences as fair or legitimate. Permeability describes the perception of whether members of one group can leave and join another group (Plante, Roberts, Reysen, \& Gerbasi, 2014).

Socio-structural variables have been used to predict collective and individual ingroup members' actions (Mummendey et al., 1999; Plante et al., 2014; Wright, 1997), ingroup bias (Bettencourt et al., 2001), prejudice (Johnson, Terry, \& Louis, 2005), and ingroup identification (Ellemers, 1993; Ellemers, Wilke, \& van Knippenberg, 1993; Verkuyten \& Reijerse, 2008). A wealth of research (e.g., Bettencourt et al, 2001) shows a general tendency for low status group members to leave one's group when the boundaries are permeable. If low status members view the boundary as impermeable, however, and the intergroup status difference as unstable, then collective action is more likely, especially if the status difference is viewed as illegitimate (Ellemers, 1993; Mummendey et al., 1999). Applied to the university context, students' perceptions of the socio-structural intergroup characteristics may predict students' behaviors toward the university. For example, if students perceive the group as low status and the boundaries are permeable, then students will likely switch schools. However, parents, friends, financial concerns, or grades may prevent the student from switching universities (i.e., low permeability). If the student is attending a high status school, the student may exert effort to maintain that positive and distinct social identity. When students are loyal and emotionally connected to the university, they are more likely to give back to the university (Beeler, 1982). While theory (Tajfel \& Turner, 1979) and prior research (e.g., Bettencourt et al., 2001; Boen \& Vanbeselaere, 2002; Mummendey et al., 1999; Verkuyten \& Reijerse, 2008) show the association between socio-structural characteristics and identification with one's group, no research has examined whether these same variables predict alumni association membership.

\subsection{Socio-Structural Characteristics and Alumni Association}

We suggest that membership in an alumni association is a sign of group members' desire to remain connected to the group. For example, wearing university apparel to connect the self with the group (Cialdini et al., 1976). Although no research has examined whether students' perception of the socio-structural intergroup characteristics predict intention to join the alumni association, prior research and theory suggests that these variables should influence the desire to remain an active member of one's group. When group status differences are perceived to be unstable and boundaries impermeable, members of low status groups show high ingroup identification and utilize collective strategies to improve group status, especially when the status differences are seen as illegitimate (Ellemers, 1993; Mummendey et al., 1999). On the other hand, when members of a low status group perceive that they can join a higher status group (i.e., high permeability), collective action is undermined (Wright, 1997). Thus, stability may predict intention or actual joining of the alumni association in that the alumni association is a vehicle that can be used to improve or maintain group status.

The permeability of the group's boundaries may predict the intention or actual joining of the alumni association. Factors such as acceptance rates, cost, and parental pressure have an influence on the perceived permeability of the groups. According to Monks and Ehrenberg (1999), an improvement in the ranking of a university results in more applications, a low acceptance rate, a reduction in financial assistance to students, and higher average SAT scores for 
admitted students. The decision on which college to attend is influenced by peer and parental pressure and whether the institution is perceived to be in line with their self-image, such as whether the university is populated with intelligent and hardworking people (Hemsley-Brown, 1999; MacAllum, Glover, Queen, \& Riggs, 2007). In addition, institutions with restrictive admissions policies tend to have more alumni willing to donate and at a higher rate (Clotfelter, 2001). When admission to a university is difficult or perceived to be difficult, students are more likely to identify with the university because restrictive admissions have the effect of projecting an exclusive group (Baade \& Sundberg, 1996). In other words, members of higher status groups may feel the boundaries are less permeable. Furthermore, students attending higher status universities may feel subjective pressure from friends and family to remain at a prestigious institution rather than exiting the group for another university. Previous studies have shown that alumni who have family members that are alumni are more likely to give back to the university (Holmes, 2009; Okunade \& Berl, 1997; Wunnava \& Lauze, 2001).

The extent to which alumni feel the status is legitimate may predict joining the alumni association. A university's legitimacy can be influenced by negative stories in the media. Although a university's total donations from all sources may not be impacted by scandals, giving by alumni is lower when an athletics team is sanctioned (Grimes \& Chressanthis, 1994; Rhoads \& Gerking, 2000). However, not all scandals lead to a drop in giving. Goff (2000) found no decrease in giving in the aftermath of the 'death penalty' (banning the school from competing in a sport for at least a year) imposed by the National Collegiate Athletic Association (NCAA) to the Southern Methodist University football program in 1986. In addition, Rhoads and Gerking (2000) found that the decrease in giving occurred for basketball related scandals but not to football related scandals. Overall, charitable giving declines in the aftermath of a scandal, although alumni giving to athletics increases (Hughes \& Shank, 2008) suggesting that highly identified alumni react to bolster the ingroup when the ingroup is perceived to be under threat (e.g., Wohl, Branscombe, \& Reysen, 2010). Scandals and bad press may impact the perceived status of the university by decreasing legitimacy.

\section{Present Study}

The purpose of the present study was to examine the association between perceptions of the socio-structural intergroup characteristics of a university and intention to join the alumni association. We suggest that joining the university alumni association is a signal of ingroup support. Following social identity theory (Tajfel \& Turner, 1979), we predict that viewing one's group as legitimately high status and in a stable position will predict greater intention to join the alumni association. In this context ingroup members are suggested to seek to maintain one's positive and dominant group position by strengthening the ingroup (i.e., joining alumni association).

\section{Method}

\subsection{Participants and Design}

Participants $\left(N=3749,63.1 \%\right.$ women; $\left.M_{\text {age }}=31.96, S D=9.81\right)$ included students from Texas A\&M University-Commerce. Students indicated their racial/ethnic category as Caucasian (60.2\%), African American (17.1\%), Hispanic (8.6\%), Asian/South Pacific Islander (5.3\%), Central Asian/Indian/Pakistani (2.8\%), Arab/Middle Eastern (2.5\%), Multiracial (1.3\%), other (1.1\%), and Indigenous Peoples (1.1\%). Students were about to earn an undergraduate $(50 \%)$, masters $(46.7 \%)$, or doctoral (3.3\%) degree. Participants were asked to rate their perception of the socio-structural characteristics of intergroup relations between A\&M-Commerce and other universities (i.e., status, permeability of group boundaries, legitimacy of status difference, stability of status difference), intention to join the alumni association, and demographic information.

\subsection{Materials}

Two items ("When A\&M-Commerce is compared to other universities, other universities have more status/power," "Other universities have more status/power than A\&M-Commerce") were reversed and combined to assess ingroup status $(\alpha=.91)$. Two items ("I think the current status/power difference between A\&M-Commerce and other universities is legitimate," "I think the current status/power difference between A\&M-Commerce and other universities is justified") were combined to assess perceived legitimacy of status differences $(\alpha=.93)$. Two items ("If I wanted to, I could have moved from A\&M-Commerce to another university," "If I wanted to, I could have left A\&M-Commerce to attend another university") were combined to assess permeability of group boundaries $(\alpha=.96)$. Two items ("The current status/power difference between A\&M-Commerce and other universities will not change easily," "I think the status/power difference between A\&M-Commerce and other universities will remain stable for many years") were combined to assess perceived stability of status differences $(\alpha=.79)$. Lastly, one item ("After 
graduation I plan to join the A\&M-Commerce Alumni Association") assessed students' intention to join the alumni association. All measures used a 7-point Likert-type response scale, from $1=$ strongly disagree to $7=$ strongly agree.

\section{Results}

As shown in Table 1, intention to join the alumni association was related to greater perceived intergroup status, permeability of group boundaries, and intergroup status stability. To examine whether intergroup socio-structural characteristics interact to predict intention to join the university alumni association upon graduation we conducted a hierarchical regression analysis. First, predictor variables (i.e., status, permeability, legitimacy, stability) were centered. Next, we constructed all possible interactions. The main effects were entered in Step 1, two-way interactions in Step 2, three-way interactions in Step 3, and the four-way interaction in Step 4. As shown in Table 2, main effects emerged showing that greater status, permeability, and stability predicted greater intention to join the alumni association. However, these were qualified by higher order interactions. Although the four-way interaction was not significant, two-way interactions were found for status and permeability, permeability and legitimacy, and a three-way interaction was observed between status, legitimacy, and stability.

Table 1. Correlations between Assessed Variables, Means (Standard Deviations)

\begin{tabular}{lllllll}
\hline Variable & Alumni & Status & Permeable & Legit & Stability & Mean (SD) \\
\hline Intention to join Alumni & 1.0 & -- & -- & -- & -- & $4.36(2.14)$ \\
Intergroup Status & $.12^{* *}$ & 1.0 & -- & -- & -- & $3.45(1.58)$ \\
Permeability of Boundaries & $.08^{* *}$ & $-.16^{* *}$ & 1.0 & -- & -- & $5.19(1.74)$ \\
Legitimacy & -.01 & $-.43^{* *}$ & $.12^{* *}$ & 1.0 & -- & $4.32(1.33)$ \\
Stability & $.04^{*}$ & $-.33^{* *}$ & $.26^{* *}$ & $.52^{* *}$ & 1.0 & $4.53(1.22)$ \\
\hline
\end{tabular}

Note. ${ }^{*} p<.05, * * p<.01 .7$-point Likert-type scale, from $1=$ strongly disagree to $7=$ strongly agree.

Table 2. Regressions of Sociostructural Intergroup Characteristics Predicting Intention to Join Alumni Association

\begin{tabular}{|c|c|c|c|c|c|c|c|c|c|c|c|c|}
\hline \multirow[b]{2}{*}{ Variable } & \multicolumn{3}{|c|}{ Step 1} & \multicolumn{3}{|c|}{ Step 2} & \multicolumn{3}{|c|}{ Step 3} & \multicolumn{3}{|c|}{ Step 4} \\
\hline & $b$ & $S E$ & $t$ & $b$ & $S E$ & $t$ & $b$ & $S E$ & $t$ & $b$ & $S E$ & $t$ \\
\hline Status & .34 & .04 & $8.80 * *$ & .33 & .04 & $8.52 * *$ & .37 & .04 & $8.79 * *$ & .37 & .04 & $8.80 * *$ \\
\hline Perm & .18 & .04 & $5.11 * *$ & .19 & .04 & $5.11 * *$ & .16 & .04 & $4.14 * *$ & .16 & .04 & $4.06^{* *}$ \\
\hline Legit & .03 & .04 & 0.71 & .03 & .04 & 0.69 & -.00 & .04 & -0.04 & -.00 & .05 & -0.03 \\
\hline Stable & .13 & .04 & $3.09 *$ & .13 & .04 & $3.00 *$ & .10 & .04 & $2.25^{*}$ & .10 & .04 & $2.24 *$ \\
\hline \multicolumn{4}{|c|}{ Status X Perm } & -.08 & .03 & $-2.47^{*}$ & -.09 & .03 & $-2.61^{*}$ & -.08 & .04 & $-2.32 *$ \\
\hline \multicolumn{4}{|c|}{ Status X Legit } & .03 & .03 & 1.01 & .04 & .03 & 1.14 & .04 & .03 & 1.21 \\
\hline \multicolumn{4}{|c|}{ Status X Stable } & .08 & .04 & $2.15^{*}$ & .08 & .04 & $2.11 *$ & .08 & .04 & $2.05^{*}$ \\
\hline \multicolumn{4}{|c|}{ Perm X Legit } & -.16 & .04 & $-4.16^{* *}$ & -.15 & .04 & $-3.76^{* *}$ & -.15 & .04 & $-3.79 * *$ \\
\hline \multicolumn{4}{|c|}{ Perm X Stable } & .06 & .04 & 1.61 & .06 & .04 & 1.51 & .05 & .04 & 1.36 \\
\hline \multicolumn{4}{|c|}{ Legit X Stable } & .12 & .08 & $4.00 * *$ & .13 & .03 & $4.19 * *$ & .13 & .03 & $4.02 * *$ \\
\hline \multicolumn{4}{|c|}{ Status X Perm X Legit } & & & & .01 & .03 & 0.19 & .00 & .03 & 0.14 \\
\hline \multicolumn{4}{|c|}{ Status X Perm X Stable } & & & & -.01 & .03 & -0.34 & -.01 & .03 & -0.30 \\
\hline \multicolumn{4}{|c|}{ Status X Legit X Stable } & & & & -.04 & .02 & $-2.11 *$ & -.04 & .02 & $-2.08^{*}$ \\
\hline \multicolumn{4}{|c|}{ Perm X Legit X Stable } & & & & .04 & .02 & 1.57 & .04 & .03 & 1.62 \\
\hline \multicolumn{7}{|c|}{ Status X Perm X Legit X Stable } & & & & -.01 & .01 & -0.45 \\
\hline$R^{2}$ Change & \multicolumn{3}{|c|}{.028} & \multicolumn{3}{|c|}{.008} & \multicolumn{3}{|c|}{.003} & \multicolumn{3}{|c|}{.000} \\
\hline$F$-Change & \multicolumn{3}{|c|}{$26.76^{* *}$} & \multicolumn{3}{|c|}{$5.44 * *$} & \multicolumn{3}{|c|}{$2.84^{*}$} & \multirow{2}{*}{\multicolumn{3}{|c|}{$\begin{array}{c}0.20 \\
(15,3733)\end{array}$}} \\
\hline$d f$ & & $(4,37$ & & & $(10,3$ & & & $(14,37$ & 34) & & & \\
\hline
\end{tabular}

Note. $* p<.05, * * p<.01$. 
As shown in Figure 1, simple slopes analysis of the two-way interaction between status and permeability showed that greater status was related to greater intention to join the alumni association when the boundaries were permeable $(b$ $=.28, S E=.05, t(3733)=5.22, p<.001)$ and impermeable $(b=.45, S E=.06, t(3733)=8.02, p<.001)$. When the ingroup was perceived to be low status, greater permeability was related to greater intent to join $(b=.24, S E=.06$, $t(3733)=4.37, p<.001)$, however, when the ingroup was high status, permeability was not significantly related to intent $(b=.07, S E=.05, t(3733)=1.45, p=.147)$.

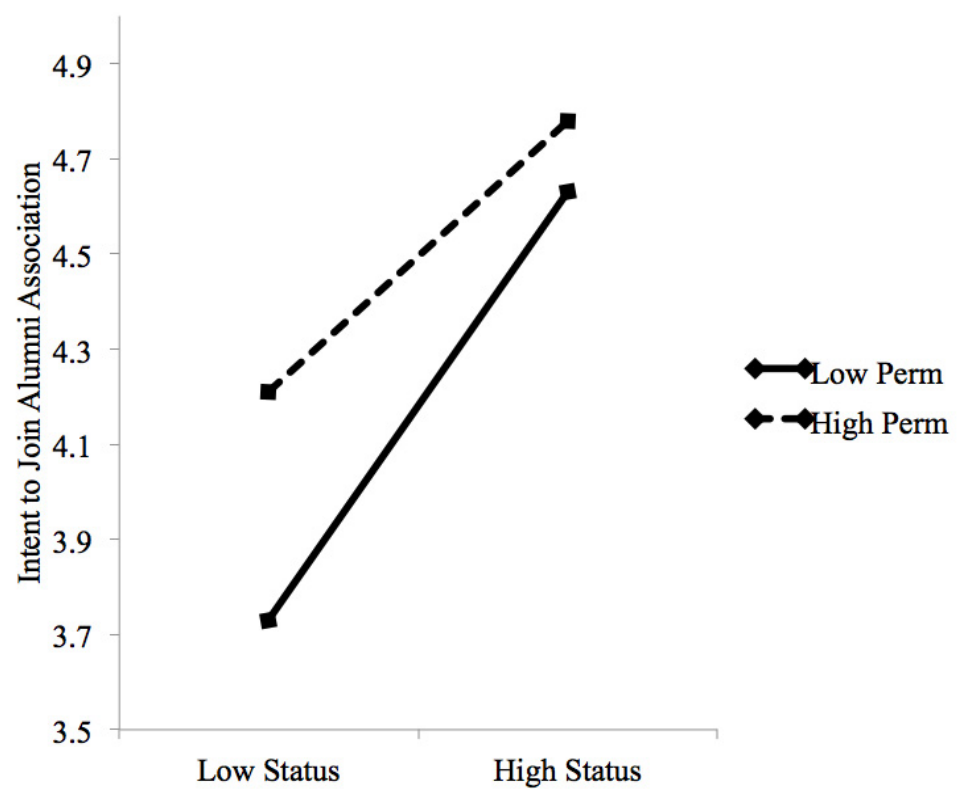

Figure 1. Interaction between Status and Permeability Predicting Intention to Join the Alumni Association

As shown in Figure 2, simple slopes analysis of the interaction between permeability and legitimacy shows that legitimacy is related to lower intent to join the alumni association when permeability is high $(b=-.15, S E=.05$, $t(3733)=-2.76, p=.006)$, and greater intention when permeability is low $(b=.15, S E=.06, t(3733)=2.33, p$ $=.020)$. The slope of permeability is significant when legitimacy is low $(b=.31, S E=.06, t(3733)=5.43, p<.001)$, but not high $(b=.01, S E=.05, t(3733)=0.15, p=.882)$.

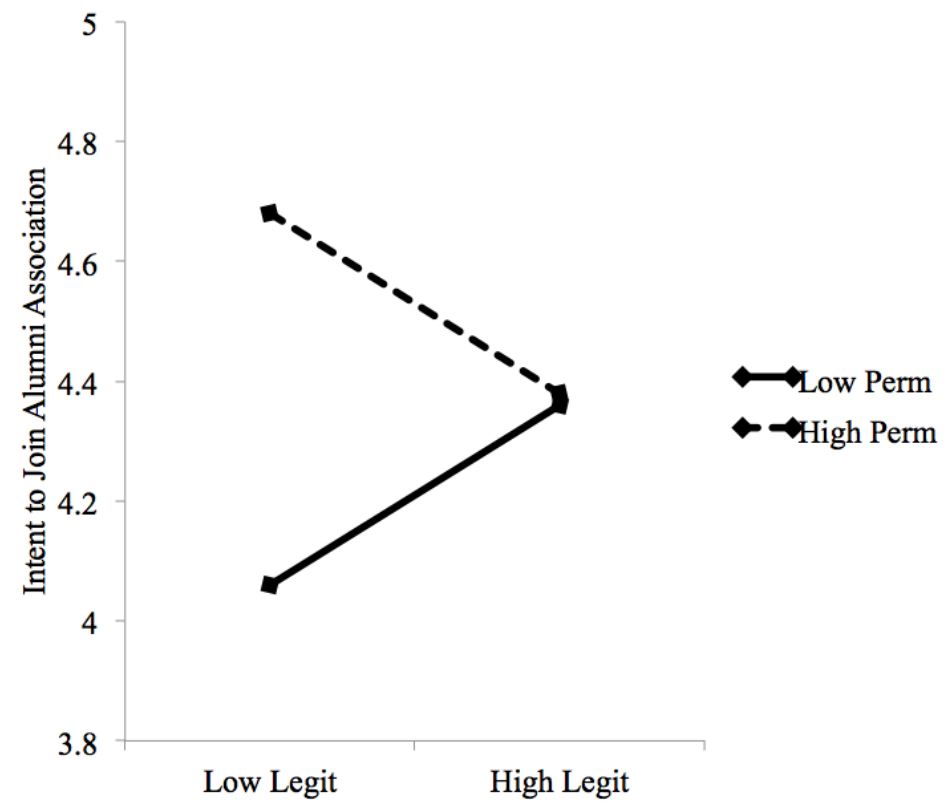

Figure 2. Interaction between Permeability and Legitimacy Predicting Intention to Join the Alumni Association 
As show in Figure 3, simple slopes analysis of the interaction between status, legitimacy, and stability showed that when participants viewed the ingroup as low status and unstable, greater legitimacy was related to less intent to join the alumni association $(b=-.17, S E=.08, t(3733)=-2.26, p=.024)$. When the ingroup was perceived as high status and the context was viewed as stable, greater legitimacy was related to greater intent to join the alumni association $(b$ $=.17, S E=.06, t(3733)=2.78, p=.006)$.

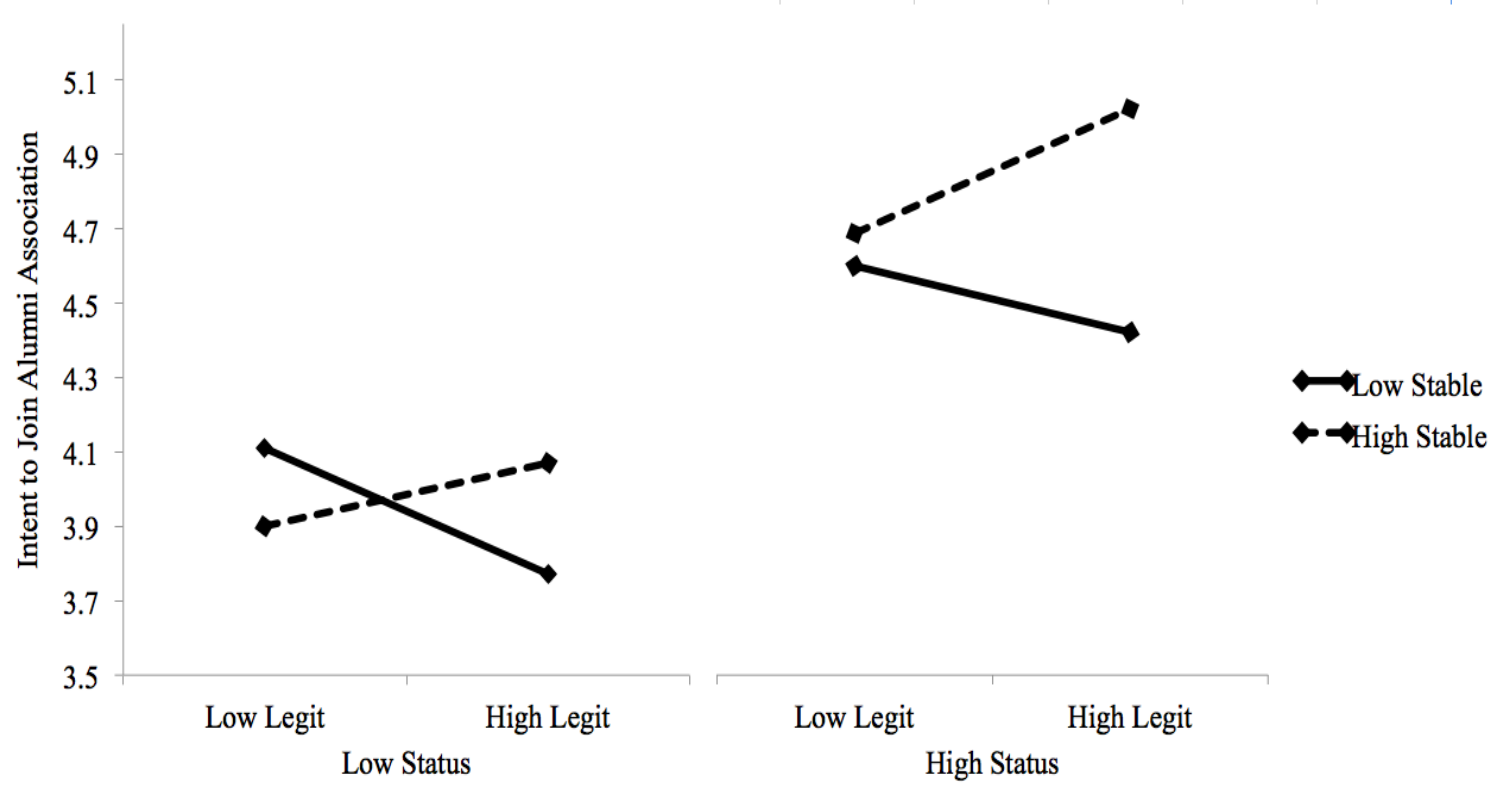

Figure 3. Interaction between Status, Legitimacy, and Stability Predicting Intention to Join the Alumni Association

\section{Discussion}

The purpose of the present study was to examine the association between perceptions of the socio-structural intergroup characteristics of a university and intention to join the alumni association. The results supported our hypothesis that viewing one's group as legitimately high status and in a stable position predicts greater intention to join the alumni association. When students viewed the university as high status and the context as stable, greater legitimacy was related to greater intent to join the alumni association. For students viewing the university as low status and unstable, greater legitimacy was related to less intent to join the alumni association. The present study showed that the desire to maintain high group status influenced group members to join the alumni association, which is a way to strengthen the ingroup.

According to social identity theory, individuals strive to gain or maintain positive and distinct social identities by comparing the ingroup to related outgroups (Tajfel \& Turner, 1979). In situations where groups differ in status, the strategies people use to maintain the positive social identity is determined by the interaction of three socio-cultural variables (stability, legitimacy, and permeability) (Bettencourt et al., 2001; Ellemers et al., 1993; Mummendey et al., 1999; Plante et al., 2014; Verkuyten \& Reijerse, 2008). In general, the present study showed that viewing the group as high status predicted greater intention to join the alumni association. This result suggests that students wish to continue to associate with a group that provides them with a positive social identity. However, when the university was perceived to be low status, greater permeability predicted greater intention to join the alumni association. Students who may have felt stuck in a low status university did not wish to continue associating with the university, while students who freely chose to attend the university did. Permeability was also found to predict greater intention to join the alumni association when the ingroup's status was illegitimate. This was an unexpected finding that is difficult to interpret. Perhaps low legitimacy was perceived as a threat which elicited a desire to protect the ingroup (e.g., Wohl et al., 2010), especially among those students who freely chose to attend the university (high permeability). However, those stuck in the illegitimate status group may desire distancing the self from the negative social identity (Snyder, Higgins, \& Stucky, 1983). Lastly, supporting the general suggestions regarding socio-structural characteristics in social identity theory (Tajfel \& Turner, 1979), students who viewed themselves as members of a legitimately high status group that was stable in the high status position predicted the most 
endorsement to join the alumni association. In other words, legitimate and stable high status predicts members' desire to remain connected to the positive social identity.

\subsection{Implications}

The findings of this study have implications for universities, especially individuals in alumni relations and development officers. As alumni donations increasingly become a major source of funds for universities, identifying the factors that influence students to join the alumni association is a key endeavor. Alumni who are current members of the alumni association were more likely to donate than alumni who were not members and compared to other donors, alumni association members contributed higher values than non-members (Newman, 2011). Thus, investing in the student experiences that contribute to the psychological factors that influence students' desire to remain connected to the university is a worthwhile effort as it bolsters perceptions of prestige and status, which influences joining of the alumni association and giving back to the university.

Studies in alumni giving have shown that alumni who have knowledge of other donors (Okunade \& Berl, 1997), seek out information about other alumni (Beeler, 1982), are involved in university related activities (Grant \& Lindauer, 1986; Holmes, 2009; Wunnava \& Lauze, 2001), and are willing to recommend the university to others (Okunade \& Berl, 1997) are more likely to donate to the university. Based on the present results, alumni relations officers and the alumni association can help with these factors by organizing events and communicating and highlighting the university's goals and legitimate achievements. Spending on alumni activities, such as events and communication, has been shown to be the leading factor to increasing donations to the university (Harrison, 1995). Alumni are more likely to donate to the university when they perceive academic quality and prestige (Baade \& Sundberg, 1996; Belfied \& Beney, 2000; Hanson, 2000; Leslie \& Ramey, 1988; Mael \& Ashforth, 1992). Thus, the results of the present research suggest communicating to students and alumni the legitimate and stable high status of the university may encourage greater connections with the university.

\subsection{Limitations}

As with any research study there are limitations to consider when interpreting the results. First, the present research was conducted at a single university. The results may vary in other cultural contexts or different schools (e.g., small liberal arts college). Second, as noted in the present paper, there are numerous factors that predict joining an alumni association and giving to the university. In the present paper we focused on factors derived from social identity theory (Tajfel \& Turner, 1979), however, other factors may be better predictors than students' perception of the socio-structural intergroup context. Future research may include additional factors beyond socio-structural characteristics to examine the unique strength of the predictors of joining the alumni association. Lastly, the present research is correlational. Future research may manipulate the intergroup context (e.g., Ellemers, 1993) to examine whether changes predict intention to join (or actual joining) of the alumni association.

\section{Conclusion}

The current study investigated the association between socio-cultural intergroup characteristics and students' intention to join the alumni association. The results showed that socio-structural intergroup characteristics interact to predict intended behavior to remain connected to the university. Supporting social identity theory, students who perceived the university as legitimately high status in a stable intergroup context predicted the highest intention to join the alumni association. Based on the growing importance of alumni donations to colleges and universities greater attention to those factors that encourage engagement with students after graduation is warranted.

\section{References}

Archibald, R. B., \& Feldman, D. H. (2006). State higher education spending and the tax revolt. Journal of Higher Education, 77, 618-644. https://doi.org/10.1353/jhe.2006.0029

Arnold, G. L. (2003). Friend raisers and fund raisers: Alumni relations and development in large, public universities (Doctoral dissertation). Available from ProQuest Dissertations and Theses database. (UMI No. 3079404)

Baade, R. A., \& Sundberg, J. O. (1996). What determines alumni generosity? Economics of Education Review, 15, 75-81. https://doi.org/10.1016/0272-7757(95)00026-7

Beeler, K. J. (1982). A study of predictors of alumni philanthropy in private universities (Doctoral dissertation). Available from ProQuest Dissertations and Theses database. (UMI No. 8216403) 
Belfield, C. R., \& Beney, A. P. (2000). What determines alumni generosity? Evidence for the UK. Education Economics, 8, 65-81. https://doi.org/10.1080/096452900110300

Bettencourt, B. A., Dorr, N., Charlton, K., \& Hume, D. L. (2001). Status differences and in-group bias: A meta-analytic examination of the effects of status stability, status legitimacy, and group permeability. Psychological Bulletin, 127, 520-542. https://doi.org/10.1037/0033-2909.127.4.520

Boen, F., \& Vanbeselaere, N. (2002). The relative impact of socio-structural characteristics on behavioral reactions against membership in a low-status group. Group Processes and Intergroup Relations, 5, 299-318. https://doi.org/10.1177/1368430202005004003

Cialdini, R. B., Borden, R. J., Thorne, A., Walker, M. R., Freeman, S., \& Sloan, L. R. (1976). Basking in reflected glory: Three (football) field studies. Journal of Personality and Social Psychology, 34, 366-375. https://doi.org/10.1037/0022-3514.34.3.366

Clotfelter, C. T. (2001). Who are the alumni donors? Giving by two generations of alumni from selective colleges. Nonprofit Management and Leadership, 12, 119-138. https://doi.org/10.1002/nml.12201

Coughlin, C. C., \& Erekson, O. H. (1984). An examination of contributions to support intercollegiate athletics. Southern Economic Journal, 51, 180-195. https://doi.org/10.2307/1058331

Drezner, N. D. (2011). Philanthropy and fundraising in American higher education (ASHE Higher Education Report, Vol. 37, No. 2). Hoboken, NJ: John Wiley \& Sons.

Duronio, M. A., \& Loessin, B. A. (1990). Fund-raising outcomes and institutional characteristics in ten types of higher education institutions. Review of Higher Education, 13, 539-556. https://doi.org/10.1353/rhe.1990.0013

Ellemers, N. (1993). The influence of socio-structural variables on identity management strategies. In W. Stroebe \& M. Hewstone (Eds.), European review of social psychology (Vol. 4, pp. 27-57). Chichester: Wiley. https://doi.org/10.1080/14792779343000013

Ellemers, N., Wilke, H., \& van Knippenberg, A. (1993). Effects of the legitimacy of low group or individual status on individual and collective identity enhancement strategies. Journal of Personality and Social Psychology, 64, 766-778. https://doi.org/10.1037/0022-3514.64.5.766

Gaier, S. (2005). Alumni satisfaction with their undergraduate academic experience and the impact on alumni giving and participation. International Journal of Educational Advancement, 5, 279-288. https://doi.org/10.1057/palgrave.ijea.2140220

Gill, J. L. (1998). Alumni programs: Principles and practice. In W. W. Tromble (Ed.), Excellence in advancement: Applications for higher education and nonprofit organizations (pp. 241-280). Gaithersburg, MD: Aspen Publishers.

Goff, B. (2000). Effects of university athletics on the university: A review and extension of empirical assessment. Journal of Sport Management, 14, 85-104. https://doi.org/10.1123/jsm.14.2.85

Grant, J. H., \& Lindauer, D. L. (1986). The economics of charity life-cycle patterns of alumnae contributions. Eastern Economic Journal, 2, 129-141.

Grimes, P. W., \& Chressanthis, G. A. (1994). Alumni contributions to academics: The role of intercollegiate sports and NCAA sanctions. American Journal of Economics and Sociology, 53, 27-40. https://doi.org/10.1111/j.1536-7150.1994.tb02669.x

Gunsalus, R. (2004). The relationship of institutional characteristics and giving participation rates of alumni. International Journal of Educational Advancement, 5, 162-170. https://doi.org/10.1057/palgrave.ijea.2140214

Hanson, S. K. (2000). Alumni characteristics that predict promoting and donating to alma mater: Implications for alumni relations (Doctoral dissertation). Available from ProQuest Dissertations and Theses database. (UMI No. 9970424)

Harrison, W. B. (1995). College relations and fund-raising expenditures: Influencing the probability of alumni giving to higher education. Economics of Education Review, 14, 73-84. https://doi.org/10.1016/0272-7757(94)00035-5

Hemsley-Brown, J. (1999). College choice: Perceptions and priorities. Educational Management and Administration, 27, 85-98. https://doi.org/10.1177/0263211X990271007

Holmes, J. (2009). Prestige, charitable deductions and other determinants of alumni giving: Evidence from a highly selective liberal arts college. Economics of Education Review, 28, 18-28. 
https://doi.org/10.1016/j.econedurev.2007.10.008

Hughes, S. F., \& Shank, M. D. (2008). Assessing the impact of NCAA scandals: An exporatory analysis. International Journal of Sport Management and Marketing, 3, 78-99. https://doi.org/10.1504/IJSMM.2008.015962

Johnson, D., Terry, D. J., \& Louis, W. R. (2005). Perceptions of the intergroup structure and anti-Asian prejudice among white Australians. Group Processes and Intergroup Relations, 8, 53-71. https://doi.org/10.1177/1368430205048616

Leslie, L. L., \& Ramey, G. (1988). Donor behavior and voluntary support for higher education institutions. The Journal of Higher Education, 59, 115-132. https://doi.org/10.2307/1981689

MacAllum, K., Glover, D. M., Queen, B., \& Riggs, A. (2007). Deciding on postsecondary education: Final report (NPEC 2008-850). Washington, DC: National Postsecondary Education Cooperative.

Mael, F., \& Ashforth, B. E. (1992). Alumni and their alma mater: A partial test of the reformulated model of organizational identification. Journal of Organizational Behavior, 13, 103-123. https://doi.org/10.1002/job.4030130202

McCormick, R. E., \& Tinsley, M. (1987). Athletics versus academics? Evidence from SAT scores. The Journal of Political Economy, 95, 1103-1116. https://doi.org/10.1086/261505

McDearmon, J. T. (2010). What's in it for me: A qualitative look into the mindset of young alumni non-donors. International Journal of Educational Advancement, 10, 33-47. https://doi.org/10.1057/ijea.2010.3

McLendon, M. K., Hearn, J. C., \& Mokher, C. G. (2009). Partisans, professionals, and power: The role of political factors in state higher education funding. The Journal of Higher Education, 80, 686-713. https://doi.org/10.1353/jhe.0.0075

Mixon, F. G., Jr. (1995). Athletics versus academics? Rejoining the evidence from SAT scores. Education Economics, 3, 277-283. https://doi.org/10.1080/09645299500000025

Mixon, F. G., Trevino, L. J., \& Minto, T. C. (2004). Touchdowns and test scores: exploring the relationship between athletics and academics. Applied Economics Letters, 11, 421-424. https://doi.org/10.1080/1350485042000201906

Monks, J. (2003). Patterns of giving to one's alma mater among young graduates from elective institutions. Economics of Education Review, 22, 121-130. https://doi.org/10.1016/S0272-7757(02)00036-5

Monks, J., \& Ehrenberg, R. G. (1999). US News \& World Report's college rankings: Why they do matter. Change: The Magazine of Higher Learning, 31, 42-51.

Mummendey, A., Klink, A., Mielke, R., Wenzel, M., \& Blanz, M. (1999). Socio-structural characteristics of intergroup relations and identity management strategies: Results from a field study in East Germany. European $\begin{array}{lllll}\text { Journal of Ssychology, } & \text { Social 259-285. }\end{array}$ https://doi.org/10.1002/(SICI)1099-0992(199903/05)29:2/3\%3C259::AID-EJSP927\%3E3.0.CO;2-F

Newman, M. D. (2011). Does membership matter? Examining the relationship between alumni association membership and alumni giving. International Journal of Educational Advancement, 10, 163-179. https://doi.org/10.1057/ijea.2011.5

Okunade, A. A., \& Berl, R. L. (1997). Determinants of charitable giving of business school alumni. Research in Higher Education, 38, 201-214. https://doi.org/10.1023/A:1024933720131

Plante, C. N., Roberts, S., Reysen, S., \& Gerbasi, K. (2014). Interaction of socio-structural characteristics predicts identity concealment and self-esteem in stigmatized minority group members. Current Psychology, 33, 3-19. https://doi.org/10.1007/s12144-013-9189-y

Pryor, J. H., Hurtado, S., Sáenz, V. B, Santos, J. L., \& Korn, W. S. (2007). The American freshman: Forty year trends. Los Angeles: Higher Education Research Institute.

Rhoads, T. A., \& Gerking, S. (2000). Educational contributions, academic quality, and athletic success. Contemporary Economic Policy, 18, 248-258. https://doi.org/10.1111/j.1465-7287.2000.tb00022.x

Snyder, C. R., Higgins, R. L., \& Stucky, R. J. (1983). Excuses: Masquerades in search of grace. New York: Wiley.

Tajfel, H., \& Turner, J. C. (1979). An integrative theory of intergroup conflict. In W. Austin \& S. Worchel (Eds.), 
The social psychology of intergroup relations (pp. 33-47). Monterey, CA: Brooks/Cole.

Verkuyten, M., \& Reijerse, A. (2008). Intergroup structure and identity management among ethnic minority and majority groups: The interactive effects of perceived stability, legitimacy, and permeability. European Journal of Social Psychology, 38, 106-127. https://doi.org/10.1002/ejsp.395

Voluntary Support of Education. (2014). Voluntary Support of Education 2013. New York: Council for Aid to Education.

Weerts, D. J., \& Ronca, J. M. (2006). Examining differences in state support for higher education: A comparative study of state appropriations for research I universities. Journal of Higher Education, 77, 935-967. https://doi.org/10.1353/jhe.2006.0054

Wohl, M. J. A., Branscombe, N. R., \& Reysen, S. (2010). Perceiving your group's future to be in jeopardy: Extinction threat induces collective angst and the desire to strengthen the ingroup. Personality and Social Psychology Bulletin, 36, 898-910. https://doi.org/10.1177/0146167210372505

Wright, S. (1997). Ambiguity, social influence, and collective action: Generating collective protest in response to tokenism. Personality and Social Psychology Bulletin, 23, 1277-1290. https://doi.org/10.1177/01461672972312005

Wunnava, P. V., \& Lauze, M. A. (2001). Alumni giving at a small liberal arts college: Evidence from consistent and occasional donors. Economics of Education Review, 20, 533-543. https://doi.org/10.1016/S0272-7757(00)00023-6 